JURNAL TERKNOSAINS

VOLUME 3

No. 2, 22 Juni 2014

Halaman 81-166

\title{
PENETUAN ALE DAN AE LARVA LEPIDIOTA STIGMA F PADA TANAMAN TEBU
}

\author{
Alimin \\ Direktorat Perlindungan Perkebunan \\ Direktorat Jenderal Perkebunan-Kementerian Pertanian Pusat \\ Email: al_ipb@yahoo.co.id \\ Edhi Martono dan Witjaksono \\ Program Studi Ilmu Hama Tumbuhan Pascasarjana \\ Fakultas Pertanian Universitas Gadjah Mada
}

\begin{abstract}
The research was conducted to determine the value of Economic Injury Level (EIL) and Economic Threshold (ET) at larvae of Lepidiota stigma instar 1, 2 and 3 in three different locations. To determine the loss of result per $m^{2}$ data on the maximum harvest outcome and harvest outcome in the field per $m^{2}$, amount of larvae population and plant per $m^{2}$ in the field and weight proportion of the vanished root or to be eaten by a larva were needed. The proportion value of the outcome loss per $m^{2}$ on the Walker Model which has been modified on biological control with Nematode Entomo Patogen (NEP) Steinernema spp., which was combined with light trap the highest is Tempel Sari i. e. larvae instar 1 (0. 0108), instar 2 (0. 0174), and instar 3 (0. 0221) and the lowest is in Grenjeng i. e. larvae instar 1 (0.0048), instar 2 (0.0078), and instar 3 (0.0099). There is significant differences among the three instars where the consume greediness of instar 3 is higher than instar 1 and 2 so that the proportion value of the outcome loss per $m^{2}$ of larvae instar 3 in the respective location is higher than the two other instars. Determination of EIL value based on Bode E Calvin Models with the highest EIL value is in Grenjeng, that are larvae instar 1 in amount of 15. 50 with ET value 12. 40; instar 2 of 9.59 with ET value 7. 67; and instar 3 in amount of 7. 54 with ET value 6. 03, while the lowest EIL value in Tempel Sari, that are larvae instar 1 in amount of 6.97 with ET value 5. 58; instar 2 of 4.31 with ET value 3. 45; and instar 3 in amount of 3. 39 with ET value 2. 71.
\end{abstract}

Keywords: Lepidiota stigma, Sugar cane, The outcome loss, Economic Injury Level, Economic Threshold

\section{ABSTRAK}

Penelitian ini dilakukan untuk menentukan nilai Aras Luka Ekonomi (ALE) dan Ambang Ekonomi (AE) larva Lepidiota stigma instar 1, 2, dan 3 pada tiga lokasi yang berbeda. Untuk menentukan kehilangan hasil per $\mathrm{m}^{2}$ diperlukan data tentang hasil panen maksimum dan hasil panen di lapangan per $\mathrm{m}^{2}$, jumlah populasi larva dan tanaman per $\mathrm{m}^{2}$ di lapangan serta proporsi berat akar yang hilang atau dimakan seekor larva. Nilai proporsi kehilangan hasil per $\mathrm{m}^{2}$ pada Model Walker yang telah dimodifikasi untuk pengendalian hayati dengan Nematoda Entomo Patogen (NEP) Steinernema spp. yang dikombinasikan dengan light trap tertinggi di Tempel Sari yaitu larva instar 1 sebesar 0,0108, instar 2 sebesar 0,0174, dan instar 3 sebesar 0,0221 dan terendah di Grenjeng yaitu larva instar 1 sebesar 0,0048, instar 2 sebesar 0,0078, 
dan instar 3 sebesar 0,0099. Terdapat perbedaan yang nyata di antara ketiga instar dimana kerakusan makan instar 3 lebih tinggi daripada instar 1 dan 2 sehingga nilai proporsi kehilangan hasil per $\mathrm{m}^{2}$ larva instar 3 pada masing-masing lokasi lebih tinggi daripada kedua instar lainnya. Penentuan nilai ALE berdasarkan Model Bode \& Calvin dengan nilai ALE tertinggi di Grenjeng, yaitu larva instar 1 sebesar 15,50 dengan nilai AE 12,40; instar 2 sebesar 9,59 dengan nilai AE 7,67; dan instar 3 sebesar 7,54 dengan nilai AE 6,03, sedangkan nilai ALE terendah di Tempel Sari, yaitu larva instar 1 sebesar 6,97 dengan nilai AE 5,58; instar 2 sebesar 4,31 dengan nilai AE 3,45; dan instar 3 sebesar 3,39 dengan nilai AE 2,71.

Kata Kunci: Lepidiota stigma, Tebu, kehilangan hasil, Aras Luka Ekonomi, Ambang ekonomi.

\section{PENGANTAR}

Program swasembada gula nasional pada tahun 2014 sulit tercapai. Program pemerintah ini merupakan upaya untuk mencukupi kebutuhan gula dalam negeri dengan target sebesar 5,8 juta ton (2,8 juta ton untuk konsumsi langsung dan 3 juta ton gula rafinasi) pada tahun 2014 (Barani, 2013). Upaya tersebut masih menemui beberapa kendala antara lain belum tersedianya lahan pertanaman tebu dan pabrik gula serta kemungkinan penurunan produksi tebu di wilayah Jawa khususnya akibat serangan Organisme Pengganggu Tanaman (OPT). Beberapa OPT penting yang menyerang tanaman tebu antara lain penggerek pucuk (Tryporiza nivella), penggerek batang bergaris (Chilo sacchariphagus), kutu bulu putih (Ceratovaguna lanigera), tikus (Rattus argentiventer dan $R$. exulans), uret atau lundi, penyakit pembuluh (ratoon stunting), dan penyakit luka api (Anonim, 1994).

Salah satu faktor yang menyebabkan turunnya produksi tebu adalah adanya hama perusak akar tebu yaitu Lepidiota stigma (Coleoptera: Scarabaeidae, Melolonthinae). Pada saat stadia larva, spesies ini merupakan hama penting bagi tanaman tebu. Hama ini banyak tersebar di Pulau Jawa, Sumatera, dan Kalimantan (Kalshoven, 1981). Selain tebu, hama ini juga menyerang tanaman lain, di antaranya ubi kayu danjagung. Serangan larva L. stigma di Pulau Jawa yang paling banyak dilaporkan, khususnya di Provinsi Jawa Tengah, D. I. Yogyakarta, dan Jawa Timur. Pada tahun 2011, produksi tebu di Kabupaten Bondowoso mengalami penurunan sampai $60 \%$ akibat serangan uret yaitu rata-rata hanya sekitar 40 ton/ha yang biasanya normal 100 ton/ha. Bahkan ada pada pertanaman petani yang tidak melakukan pengendalian hanya menghasilkan 5 ton per ha (Anonim, 2011).

Larva L. stigma memakan perakaran tebu sehingga sistem akar lemah, mudah rebah jika ditiup angin dan akhirnya tanaman mati. Menurut Allsopp bahwa tanaman yang terserang menjadi kuning, kering dan mati, akhirnya mengakibatkan kehilangan hasil yang signifikan. Penggunaan pemanen mekanik dapat menurunkan sisa-sisa populasi uret, tetapi dapat mengurangi kemampuan tanaman untuk menghasilkan ratoon dan terpaksa petani menanam kembali sehingga biaya yang dikeluarkan dua kali lipat (Allsopp et al., 2000).

Pengelolaan uret L. stigma dapat dilakukan dengan menggunakan pendekatan Pengendalian Hama Terpadu (PHT) yang didasarkan pada pertimbangan ekologi, efisiensi, dan pengelolaan agroekosistem yang bertanggung jawab dan berkelanjutan. Pengendalian kimiawi tidak perlu dilakukan jika populasi uret masih berada di bawah ambang ekonomi. Pengendalian uret $L$. stigma akan lebih tepat jika dilakukan secara spesifik lokasi dengan memadukan beberapa cara pengendalian sesuai kondisi daerah.

Selama ini belum ada laporan penelitian tentang penentuan Aras Luka Ekonomi (ALE) atau Economic Injury Level (EIL) dan Ambang Ekonomi (AE) atau Economic Treshold (ET) pada larva L. stigma. Nilai ALE dan AE larva L. stigma yang menyerang tanaman tebu pada lokasi yang berbeda dapat bervariasi berdasarkan tingkat kerusakan akar tanaman dan hasil panen yang ditimbulkannya. Oleh sebab itu, perlu adanya penentuan nilai 
ALE dan AE hama tersebut pada lokasi yang berbeda dalam upaya pengambilan keputusan pengendalian di lapangan.

Masalah yang dibahas dalam penelitian ini adalah (1) seberapa besar proporsi kerusakan akar tanaman tebu apabila diinfestasi dengan larva L. stigma instar 1, instar 2, dan instar 3 serta (2) seberapa besar nilai ALE dan AE larva L. stigma pada tiga lokasi yang berbeda agar dapat dipergunakan sebagai dasar keputusan pengendaliannya.

Stern adalah orang yang pertama kali memperkenalkan konsep ALE pada tahun 1959 sebagai kepadatan populasi hama terendah yang akan menyebabkan kerusakan ekonomi. Konsep ini lebih menekankan pada kerusakan ekonomi yang akan ditimbulkan oleh hama dan belum memberikan informasi tentang respon tanaman terhadap serangan hama. Pada tahun 1990, Bode dan Calvin mengembangkan model ALE yang sedikit berbeda dengan model ALE yang dikembangkan oleh Pedigo, tetapi masih dengan pengertian aras luka ekonomi yang sama, yaitu ALE = TC/ (CV x PL x PC), CV $=\mathrm{MV} \times \mathrm{EY}$, dengan $\mathrm{TC}=$ total biaya untuk sekali pengendalian termasuk upah tenaga pengendalian $(\mathrm{Rp} / \mathrm{ha}), \mathrm{PL}=$ proporsi kehilangan hasil per larva per tanaman, $\mathrm{CV}=$ nilai tanaman, MV = harga hasil tanaman di pasaran $(\mathrm{Rp} / \mathrm{kg}), \mathrm{EY}=$ prediksi hasil panen $(\mathrm{kg} / \mathrm{ha})$, dan $\mathrm{PC}=$ proporsi penurunan populasi hama karena tindakan pengendalian (Pedigo et al. , 1986).

Menurut Walker (1983) dalam Tatchell (1989) kehilangan hasil oleh hama didefinisikan sebagai perbedaan antara hasil panen yang diperoleh pada tanaman yang tidak terserang hama yang diteliti (Yp) dengan hasil panen yang diperoleh bila tanaman terserang oleh hama yang diteliti $(\mathrm{Yr})$. Perbedaan hasil ini disebut sebagai proporsi kehilangan hasil dan dapat dihitung dengan rumus $r=(Y p-Y r) / Y p$.

Menurut Higley \& Pedigo (1996) AE didefinisikan sebagai kepadatan populasi hama yang dilakukan tindakan pengen- dalian seperti penggunaan pestisida, pengendalian hayati, kultur teknis, dan lainlain untuk mencegah terjadinya peningkatan populasi hama agar tidak mencapai ambang kerusakan ekonomi atau ALE. Dengan kata lain AE sebenarnya merupakan waktu untuk mengambil tindakan pengendalian terhadap hama pada kepadatan populasi hama tertentu.

Belum ada rumus untuk menghitung nilai AE secara pasti, tetapi secara umum dapat ditentukan pada persentase tetap dari nilai ALE (fixed economic threshold), misalnya penentuan nilai AE $80 \%$ dari nilai ALE (Asia-Pasific Regional Technology Centre (APRTC, 2002) dan 50\% atau $70 \%$ dari nilai ALE (Pedigo, 2009). Penentuan nilai AE yang lebih baik adalah memperhitungkan laju peningkatan populasi hama dan tingkat kerusakan hama atau descriptive economic threshold (Pedigo, 2009). Semakin cepat laju peningkatan populasi hama semakin lebar jarak nilai AE di bawah nilai ALE dan apabila sifat dinamika populasi hama kurang diketahui, maka nilai AE ditetapkan sedikit di bawah nilai ALE (Untung, 2006).

Penelitian ini dilakukan selama 7 bulan yaitu bulan Januari-Juni 2013 dan bulan Januari 2014. Tempat kegiatan penelitian dilakukan di Laboratorium Pengendalian Hayati, Faperta UGM; rumah kaca PusatStudi Sumberdaya Lahan UGM; areal lahan tebu petani di Desa Purwomartani dan kediaman penulis yaitu di Desa Wedomartani, tetangga Desa Purwomartani, Kecamatan Kalasan, Kabupaten Sleman, Yogyakarta.

Pengadaan bibit tebu sebagian besar menggunakan varietas PS 862 dari lahan pembibitan petani tebu Desa Purwomartani, Kecamatan Kalasan, Sleman, kemudian ditanam dalam pot-pot bervolume 5 liter dengan campuran tanah dan pupuk kandang dengan perbandingan 3:1. Pot-pot tanaman tebu dipelihara di rumah kaca Pusat Studi Sumberdaya Lahan UGM dan kediaman penulis. Sedangkan larva L. stigma instar 1, 2, dan 3 diperoleh dari lahan pertanaman tebu Desa Purwomartani. Sebelum diinfestasi 
ke dalam pot-pot tanaman, stadia larva instar 1, 2 dan 3 dipelihara di Laboratorium Pengendalian Hayati, Faperta UGM.

Pada percobaan penentuan proporsi berat akar yang hilang atau dimakan larva terdiri dari perlakuan kemampuan makan larva instar 1, 2, dan 3 yang masingmasing 5 ulangan, serta kontrol pada setiap perlakuannya. Umur tanaman tebu yang akan diinfestasikan larva instar 1, 2, dan 3 berturut-turut 45 hari setelah tanam (hst), 95 hst, dan 111 hst. Pada setiap pot perlakuan diinfestasi satu ekor baik larva instar 1, 2 dan 3 dan kontrol tanpa larva. Setelah 10 hari sejak diinfestasi, pot tanaman dibongkar dan dilakukan pengukuran berat basah akar dan selanjutnya menentukan proporsi berat akar yang hilang atau dimakan oleh seekor larva instar 1, 2, dan 3 per tanaman.

Lokasi pengambilan sampel populasi larva, populasi tanaman, dan hasil panen tanaman merupakan daerah endemis hama perusak akar tebu L. stigma yang berada di Desa Purwomartani. Pengambilan sampel dilakukan pada 3 blok sampel yang mewakili dusun-dusun yang ada di Desa Purwomartani, yaitu blok 1 (Dusun Tempel Sari), Blok 2 (Dusun Kujon Sari), dan blok 3 (Dusun Grenjeng). Setiap blok sampel yang berukuran $900 \mathrm{~m}^{2}(30 \times 30 \mathrm{~m})$ ditentukan 4 titik sampel seluas $1 \mathrm{~m}^{2}$ secara acak sistematik satu diagonal. Selanjutnya melakukan pengamatan untuk menghitung jumlah larva (ekor $/$ meter $^{2}$ ) dengan menggali tanah sampai kedalaman $30-50 \mathrm{~cm}$ dan jumlah tanaman (batang/ meter $^{2}$ ) serta hasil panen $\left(\mathrm{kg} /\right.$ meter $\left.^{2}\right)$ dengan menimbang panjang batang yang diukur dari pangkal batang sampai ujung batang atas.

Proporsi kehilangan hasil dihitung berdasarkan rumus Walker (1983) dalam Tatchell (1989), yaitu $\mathrm{r}$ atau PL $=(\mathrm{Yp}-\mathrm{Yr}) /$ $\mathrm{Yp}$, dengan $\mathrm{PL}=$ proporsi kehilangan hasil, $\mathrm{Yp}=$ hasil panen pada kontrol, dan $\mathrm{Yr}=$ hasil panen yang diperoleh dari perlakuan. Pada penelitian ini nilai PL diperoleh atau dikembangkan berdasarkan teknik pengendalian secara hayati dengan menggunakan NEP Steinernema spp. yang dikombinasikan dengan perangkap lampu (light trap), nilai rata-rata proporsi injury atau kehilangan berat akar (satu ekor larva per tanaman) pada percobaan di rumah kaca, rata-rata jumlah populasi larva dan tanaman, serta hasil panen permeter ${ }^{2}$ di lapangan, kemudian dibandingkan terhadap potensi hasil panen maksimum. Jadi nilai proporsi kehilangan hasil permeter ${ }^{2}$ yang telah dimodifikasi berdasarkan model Walker adalah $\mathrm{PL}=\{(\mathrm{Yp}-\mathrm{Yf}) \times \mathrm{Cf}\} / \mathrm{Yp}$ dengan $\mathrm{Cf}$ $=(\operatorname{Pr} \times \mathrm{Pi}) / \mathrm{Pt}$, di mana $\mathrm{Yp}=$ potensi hasil panen maksimum $\left(\mathrm{kg} / \mathrm{m}^{2}\right) ; \mathrm{Yf}=$ hasil panen di lapang $\left(\mathrm{kg} / \mathrm{m}^{2}\right)$; $\mathrm{Cf}=$ faktor koreksi; $\mathrm{Pr}=$ proporsi akar hilang per larva per tanaman; $\mathrm{Pi}$ $=$ jumlah populasi hama di lapang permeter $^{2}$, dan $\mathrm{Pt}=$ jumlah populasi tanaman permeter ${ }^{2}$.

Nilai ALE per satuan luas $\mathrm{m}^{2}$ dihitung berdasarkan model yang dikembangkan oleh Bode \& Calvin (1990) dengan rumus ALE = $\mathrm{TC} /(\mathrm{CV} \times \mathrm{PL} \times \mathrm{PC})$ atau ALE $=\mathrm{TC} /\{(\mathrm{MV} \times$ EY) $\times$ PL $\times$ PC, dimana TC = total biaya untuk sekali pengendalian termasuk upah tenaga kerjanya $(\mathrm{Rp} / \mathrm{ha}), \mathrm{PL}=$ proporsi kehilangan hasil permeter ${ }^{2}, \mathrm{CV}=$ nilai tanaman $(\mathrm{Rp} /$ ha), $\mathrm{MV}=$ harga hasil tanaman di pasaran $(\mathrm{Rp} / \mathrm{kg}), \mathrm{EY}=$ potensi hasil maksimum tanaman $(\mathrm{kg} / \mathrm{ha})$, dan $\mathrm{PC}=$ proporsi penurunan populasi hama karena tindakan pengendalian. Pada penelitian ini ditentukan nilai AE sebesar 80\% dari nilai ALE.

\section{PEMBAHASAN}

Pada Tabel 1 diperoleh nilai ratarata berat akar yang hilang dari tertinggi berturut-turut adalah instar 3 (32,31 gram), instar 2 (8,26 gram), dan instar 1 (0,44 gram) sehingga diperoleh nilai proporsi kehilangan berat akar yang dimakan oleh larva L. stigma pada instar 1, 2, dan 3 secara berturut-turut adalah sebesar 0,1773; 0,2867; dan 0,3645. Pada Uji-T berat akar hilang pada instar 1, 2 dan 3 terdapat perbedaan yang nyata diantara ketiganya. 
Tabel 1.

Berat Akar yang Hilang atau Dimakan oleh Larva L. Stigma Instar 1, 2, dan 3.

\begin{tabular}{llrrrr}
\hline \multicolumn{1}{c}{ Berat akar hilang } & \multicolumn{1}{c}{ Rata-rata (gr) } & t- hit & t- tab & Sig. & Kesimpulan \\
\hline Instar 1 & 0,44 & -4.477 & 2,776 & 0,011 & Ada perbedaan \\
Instar 2 & 8,26 & & & & \\
Instar 1 & 0,44 & $-7,197$ & 3,182 & 0,006 & Ada perbedaan \\
Instar 3 & 32,31 & & & & \\
Instar 2 & 8,26 & $-5,054$ & 3,182 & 0,008 & Ada perbedaan \\
Instar 3 & 32,31 & & & & \\
\hline
\end{tabular}

Populasi larva L. stigma permeter ${ }^{2}$ pada ketiga lokasi yaitu Dusun Tempel Sari, Kujon Sari, dan Grenjeng menunjukkan tidak ada perbedaan yang nyata di antara ketiganya, seperti pada Tabel 2. Nilai rata-rata populasi larva pada ketiga lokasi berturut-turut dari yang tertinggi adalah Tempel Sari 5 ekor, Kujon Sari 3 ekor, dan Grenjeng 2 ekor.
Populasi tanaman per $\mathrm{m}^{2}$ pada ketiga lokasi yaitu Dusun Tempel Sari, Kujon Sari, dan Grenjeng dapat ditunjukkan pada Tabel 3. Ada perbedaan yang nyata antara populasi tanaman Tempel Sari dan kujon Sari serta Tempel Sari dan Grenjeng, sedangkan Kujon Sari dan Grenjeng tidak terdapat perbedaan yang nyata.

Tabel 2.

Populasi Larva L. Stigma Permeter ${ }^{2}$ pada Ketiga Lokasi yaitu Dusun Tempel Sari, Kujon Sari, dan Grenjeng

\begin{tabular}{llrrrr}
\hline \multicolumn{1}{c}{ Populasi larva } & Rata-rata (ekor) & t- hit & t- tab & Sig. & Kesimpulan \\
\hline Tempel Sari & 5,00 & $-1,188$ & 2,447 & 0,280 & Tidak ada perbedaan \\
Kujon sari & 3,00 & & & & \\
Tempel sari & 5,00 & 2,038 & 2,447 & 0,088 & Tidak ada perbedaan \\
Grenjeng & 2,00 & & & & \\
Kujon Sari & 3,00 & 0,775 & 2,447 & 0,468 & Tidak ada perbedaan \\
Grenjeng & 2,00 & & & & \\
\hline
\end{tabular}

Tabel 3.

Populasi Tanaman Tebu Permeter ${ }^{2}$ pada Ketiga Lokasi yaitu Dusun Tempel Sari, Kujon Sari, dan Grenjeng

\begin{tabular}{llrrrr}
\hline Populasi Tanaman & Rata-rata (batang) & t- hit & t- tab & Sig. & Kesimpulan \\
\hline Tempel Sari & 17,75 & 4,255 & 2,447 & 0,005 & Ada perbedaan \\
Kujon sari & 9,00 & & & & \\
Tempel sari & 17,75 & 3,770 & 2,447 & 0,009 & Ada perbedaan \\
$\begin{array}{l}\text { Grenjeng } \\
\text { Kujon Sari }\end{array}$ & 10,25 & & & & \\
Grenjeng & 9,00 & 0,951 & 2,447 & 0,379 & Tidak ada perbedaan \\
\hline
\end{tabular}

Hasil panen tanaman permeter persegi (permeter ${ }^{2}$ ) pada ketiga lokasi yaitu Dusun Tempel Sari, Kujon Sari, dan Grenjeng dapat ditunjukkan pada Tabel 4. Ukuran panjang batang tanaman yang ditimbang berkisar antara 1,00-2,50 m. Nilai rata-rata hasil panen tanaman pada ketiga lokasi berturut-turut dari yang tertinggi adalah Kujon Sari 9,30 kg, Grenjeng 9,10 kg, dan Tempel Sari 8,30 kg. 
Tabel 4.

Hasil Panen Tanaman Tebu Permeter ${ }^{2}$

pada Ketiga Lokasi yaitu Dusun Tempel Sari, Kujon Sari, dan Grenjeng

\begin{tabular}{llrrrl}
\hline \multicolumn{1}{c}{ Hasil panen } & \multicolumn{1}{c}{ Rata-rata $\mathbf{( k g )}$} & $\mathbf{t}$ - hit & $\mathbf{t}$ - tab & Sig. & Kesimpulan \\
\hline Tempel Sari & 8,30 & $-2,887$ & 2,447 & 0,028 & Ada perbedaan \\
Kujon sari & 9,30 & & & & \\
Tempel sari & 8,30 & $-2,191$ & 2,447 & 0,071 & Tidak ada perbedaan \\
$\begin{array}{l}\text { Grenjeng } \\
\text { Kujon Sari }\end{array}$ & 9,10 & & & & \\
Grenjeng & 9,30 & 0,667 & 2,447 & 0,530 & Tidak ada perbedaan \\
\hline
\end{tabular}

Hasil panen tanaman antara Tempel Sari dan Kujon Sari terdapat perbedaan yang nyata, sedangkan antara Tempel Sari dan Kujon Sari, Kujon Sari, dan Grenjeng tidak terdapat perbedaan yang nyata.

Proporsi kehilangan hasil permeter ${ }^{2}$ menurut model Walker yang telah dimodifikasi, nilai tertinggi terdapat di lokasi Tempel Sari yaitu larva instar 1 sebesar 0,0108, instar 2 sebesar 0,0174, dan instar 3 sebesar 0,0221. Sedangkan proporsi kehilangan hasil permeter ${ }^{2}$ terendah terdapat di lokasi Grenjeng yaitu larva instar 1 sebesar 0,0048, instar 2 sebesar 0,0078, dan instar 3 sebesar 0,0099 (Tabel 5).
Pada Tabel 6, nilai ALE dan AE per satuan luas meter ${ }^{2}$ berdasarkan model Bode dan Calvin untuk pengendalian secara hayati dengan NEP Steinernema spp. yang dikombinasikan dengan light trap pada ketiga lokasi tertinggi di lokasi Grenjeng, yaitu larva instar 1 sebesar 15,50 dengan nilai AE 12,40; instar 2 sebesar 9,59 dengan nilai AE 7,67; dan instar 3 sebesar 7,54 dengan nilai AE 6,03. Sedangkan nilai ALE terendah di lokasi Tempel Sari, yaitu larva instar 1 sebesar 6,97 dengan nilai AE 5,58; instar 2 sebesar 4,31 dengan nilai AE 3,45; dan instar 3 sebesar 3,39 dengan nilai AE 2,71.

Tabel 5.

Proporsi Kehilangan Hasil Permeter ${ }^{2}$

pada Berbagai Stadia Larva L. Stigma di Dusun Tempel Sari, Kujon Sari, dan Grenjeng

\begin{tabular}{|c|c|c|c|c|c|c|}
\hline Lokasi & Stadia larva & Yp-Yf & $\begin{array}{c}\text { Cf } \\
(\operatorname{Pr} \times \text { Pi)/Pt }\end{array}$ & $(Y p-Y f) \times C f$ & $\begin{array}{c}P L \\
\{(Y p-Y f) \times C f\} / Y p\end{array}$ & $\%$ PL \\
\hline \multirow[t]{3}{*}{ Tempel sari } & Instar 1 & 2,28 & 0,0499 & 0,114 & 0,0108 & 1,08 \\
\hline & Instar 2 & 2,28 & 0,0808 & 0,184 & 0,0174 & 1,74 \\
\hline & Instar 3 & 2,28 & 0,1027 & 0,234 & 0,0221 & 2,21 \\
\hline \multirow[t]{3}{*}{ Kujon Sari } & Instar 1 & 1,28 & 0,0591 & 0,076 & 0,0072 & 0,72 \\
\hline & Instar 2 & 1,28 & 0,0956 & 0,122 & 0,0116 & 1,16 \\
\hline & Instar 3 & 1,28 & 0,1215 & 0,156 & 0,0147 & 1,47 \\
\hline \multirow[t]{3}{*}{ Grenjeng } & Instar 1 & 1,48 & 0,0346 & 0,051 & 0,0048 & 0,48 \\
\hline & Instar 2 & 1,48 & 0,0559 & 0,083 & 0,0078 & 0,78 \\
\hline & Instar 3 & 1,48 & 0,0711 & 0,105 & 0,0099 & 0,99 \\
\hline
\end{tabular}

Ket : Yp = potensi hasil panen maksimum $\left(\mathrm{kg} / \mathrm{m}^{2}\right) ; \mathrm{Yf}=$ hasil panen tanaman di lapang $\left(\mathrm{kg} / \mathrm{m}^{2}\right) ; \mathrm{Cf}=$ faktor koreksi; Pr = proporsi akar hilang per larva pertanaman; $\mathrm{Pi}=$ jumlah populasi hama di lapang permeter ${ }^{2}$, dan $\mathrm{Pt}=$ jumlah populasi tanaman permeter $^{2}$. 
Tabel 6.

Nilai ALE dan AE larva L. Stigma permeter ${ }^{2}$ dengan Pengendalian Secara Hayati Menggunakan NEP Steinernema spp. yang Dikombinasikan dengan Light Trap di Lokasi Tempel Sari, Kujon Sari, dan Grenjeng

\begin{tabular}{llccccccc}
\hline Lokasi & Stadia Larva & TC & $\begin{array}{c}\text { CV } \\
\text { (MVxEY) }\end{array}$ & PC & TC/(CVxPC) & PL & $\begin{array}{c}\text { ALE } \\
/ \mathbf{m}^{2}\end{array}$ & $\begin{array}{c}\text { AE } \\
/ \mathbf{m}^{2}\end{array}$ \\
\hline TS & Instar 1 & 2.500 .000 & 47.610 .000 & 0,70 & 0,075 & 0,0108 & 6,97 & 5,58 \\
& Instar 2 & 2.500 .000 & 47.610 .000 & 0,70 & 0,075 & 0,0174 & 4,31 & 3,45 \\
& Instar 3 & 2.500 .000 & 47.610 .000 & 0,70 & 0,075 & 0,0221 & 3,39 & 2,71 \\
\multirow{2}{*}{ KS } & Instar 1 & 2.500 .000 & 47.610 .000 & 0,70 & 0,075 & 0,0072 & 10,49 & 8,39 \\
& Instar 2 & 2.500 .000 & 47.610 .000 & 0,70 & 0,075 & 0,0116 & 6,49 & 5,19 \\
& Instar 3 & 2.500 .000 & 47.610 .000 & 0,70 & 0,075 & 0,0147 & 5,10 & 4,08 \\
\multirow{2}{*}{ Gj } & Instar 1 & 2.500 .000 & 47.610 .000 & 0,70 & 0,075 & 0,0048 & 15,50 & 12,40 \\
& Instar 2 & 2.500 .000 & 47.610 .000 & 0,70 & 0,075 & 0,0078 & 9,59 & 7,67 \\
& Instar 3 & 2.500 .000 & 47.610 .000 & 0,70 & 0,075 & 0,0099 & 7,54 & 6,03 \\
\hline
\end{tabular}

Ket: TS = Tempel Sari, KS = Kujon Sari, Gj = Grenjeng

$\mathrm{TC}=$ total biaya pengendalian secara hayati termasuk upah pengendaliannya $(\mathrm{Rp} / \mathrm{ha}), \mathrm{PL}=$ proporsi kehilangan hasil permeter ${ }^{2}, \mathrm{CV}=$ nilai tanaman $(\mathrm{Rp} / \mathrm{ha}), \mathrm{MV}=$ harga hasil tanaman di pasaran $(\mathrm{Rp} / \mathrm{kg}), \mathrm{EY}=$ potensi hasil panen tanaman maksimum $(\mathrm{kg} / \mathrm{ha}), \mathrm{dan} \mathrm{PC}=\mathrm{proporsi}$ penurunan populasi hama karena tindakan pengendalian.

\section{Proporsi Kehilangan Hasil}

Proporsi kehilangan hasil per $\mathrm{m}^{2}$ dihitung berdasarkan model Walker yaitu $\mathrm{r}$ atau atau $\mathrm{PL}=(\mathrm{Yp}-\mathrm{Yr}) / \mathrm{Yp}$, dengan $\mathrm{r}=$ proporsi kehilangan hasil, $\mathrm{Yp}=$ hasil panen pada kontrol, dan $\mathrm{Yr}=$ hasil panen yang diperoleh dari perlakuan. Pada penelitian ini menggunakan model Walker yang telah dimodifikasi untuk menentukan nilai proporsi kehilangan hasil persatuan luas $\mathrm{m}^{2}$ yaitu $\mathrm{PL}=\{(\mathrm{Yp}-\mathrm{Yf}) \times \mathrm{Cf}\} / \mathrm{Yp}$ dengan $\mathrm{Cf}$ $=(\operatorname{Pr} \times \mathrm{Pi}) / \mathrm{Pt}$, di mana $\mathrm{Yp}=$ potensi hasil panen tanaman maksimum $\left(\mathrm{kg} / \mathrm{m}^{2}\right)$; $\mathrm{Yf}=$ hasil panen tanaman di lapang $\left(\mathrm{kg} / \mathrm{m}^{2}\right)$; Cf = faktor koreksi; Pr = proporsi berat akar hilang per larva per tanaman; $\mathrm{Pi}=$ jumlah populasi hama di lapang permeter ${ }^{2}$, dan $\mathrm{Pt}=$ jumlah populasi tanaman permeter ${ }^{2}$.

Nilai proporsi kehilangan hasil diperoleh berdasarkan teknik pengendalian hayati dengan NEP Steinernema spp. yang dikombinasikan dengan light trap, data hasil panen, proporsi berat akar hilang, dan populasi tanaman per satuan luas $\mathrm{m}^{2}$. Dari penelitian diperoleh hasil panen tanaman per $\mathrm{m}^{2}$ di Tempel Sari, Kujon Sari, dan Grenjeng berturut-turut adalah 8,30 $\mathrm{kg}$, 9,30 kg, dan 9,10 kg; sedangkan potensi hasil panen tanaman dengan varietas PS 862 adalah sebesar 10, $58 \mathrm{~kg}$ per $\mathrm{m}^{2}$. Nilai Pr atau proporsi berat akar hilang adalah proporsi berat akar yang dimakan oleh larva L. stigma instar 1, 2 dan 3 berturut-turut sebesar 0,1773; 0,2867; dan 0,3645. Nilai Pi adalah rata-rata jumlah populasi larva per $\mathrm{m}^{2}$ di Tempel Sari, Kujon Sari, dan Grenjeng berturut-turut yaitu 5 ekor; 3 ekor; dan 2 ekor. Sedangkan nilai $\mathrm{Pt}$ adalah rata-rata jumlah populasi tanaman per $\mathrm{m}^{2}$ di Tempel Sari, Kujon Sari, dan Grenjeng berturut-turut yaitu 17,75 batang; 9 batang; dan 10,25 batang.

Perhitungan nilai proporsi kehilangan hasil permeter ${ }^{2}$ (PL) akibat larva L. stigma instar 1, 2, dan 3 misalnya di lokasi Tempel Sari yaitu selisih antara potensi hasil tanaman maksimum dan hasil panen tanaman di lapangan (Yp - Yf) sebesar 2,28 kg/ $\mathrm{m}^{2}$, nilai Cf atau (Pr x Pi)/Pt untuk instar 1, 2 dan 3 berturut-turut sebesar 0,0499; 0,0808; dan 0,1027, jika dikalikan antara nilai (Yp -Yf) dan Cf menghasilkan berturut-turut sebesar 0,114; 0,184; dan 0,234, maka akan menghasilkan nilai PL berturut-turut sebesar $0,0108(1,08 \%) ; 0,0174(1,74 \%)$; dan 0,0221 $(2,21 \%)$.

Proporsi kehilangan hasil per $\mathrm{m}^{2}$ pada ketiga lokasi dari yang tertinggi berturutturut adalah Tempel Sari, Kujon Sari dan 
Grenjeng. Kerakusan makan berdasarkan proporsi berat akar hilang atau yang dimakan larva adalah faktor penyebabnya. Kerakusan makan instar 3 lebih tinggi daripada instar 1 dan 2 serta terdapat perbedaan yang nyata di antara ketiga instar tersebut. Data ini mengindikasikan bahwa larva instar 3 lebih rakus memakan akar tebu daripada instar 1 dan 2 karena ukuran bentuk tubuh instar 3 lebih besar, selain itu juga pada stadia ini membutuhkan energi yang lebih besar sebagai bentuk persiapan diri dalam menghadapi stadia prapupa kemudian pupa.

Semakin rendah jumlah populasi larva permeter ${ }^{2}$, maka semakin rendah pula nilai proporsi kehilangan hasil. Sebaliknya semakin rendah jumlah populasi tanaman per $\mathrm{m}^{2}$, maka semakin tinggi nilai proporsi kehilangan hasil persatuan luas tersebut. Pada penelitian ini diperoleh jumlah populasi larva permeter ${ }^{2}$ antara ketiga lokasi tersebut tidak ada perbedaan yang nyata. Sedangkan jumlah populasi tanaman per $\mathrm{m}^{2}$, hanya antara Kujon Sari dan Grenjeng yang tidak menunjukkan perbedaan nyata.

\section{ALE dan AE larva L. Stigma}

Nilai ALE per satuan luas meter $^{2}$ dihitung berdasarkan model ALE yang dikembangkan oleh Bode \& Calvin (1990) yaitu $\mathrm{ALE}=\mathrm{TC} /(\mathrm{CV} \times \mathrm{PL} \times \mathrm{PC})$ atau $\mathrm{ALE}=$ $\mathrm{TC} /\{(\mathrm{MV} \times \mathrm{EY}) \times \mathrm{PL} \times \mathrm{PC}$, dimana $\mathrm{TC}=$ total biaya untuk sekali pengendalian termasuk upah tenaga kerjanya ( $\mathrm{Rp} / \mathrm{ha}), \mathrm{PL}=$ proporsi kehilangan hasil per $\mathrm{m}^{2}, \mathrm{CV}=$ nilai tanaman (Rp/ha), MV = harga hasil tanaman di pasaran $(\mathrm{Rp} / \mathrm{kg}), \mathrm{EY}=$ potensi hasil panen tanaman maksimum (kg/ha), dan $\mathrm{PC}=$ proporsi penurunan populasi hama karena tindakan pengendalian.

Biaya pengendalian pada penelitian ini diperoleh berdasarkan pengalaman petani dalam melakukan pengendalian di Desa Purwomartani, Kecamatan Kalasan, Sleman. Sebenarnya ada dua teknik pengendalian berdasarkan pengalaman yang telah dilakukan oleh petani yaitu dengan menggunakan pestisida berbahan aktif karbofuran dan pengendalian hayati dengan menggunakan NEP Steinernema spp. yang dikombinasikan dengan light trap (Anonim, 2012). Akan tetapi, untuk menghindari biaya lingkungan akibat dampak pengendalian dengan menggunakan pestisida, maka biaya pengendalian dihitung berdasarkan biaya pengendalian secara hayati. Nilai tanaman (CV) diperoleh berdasarkan hasil survey harga tebu di tingkat petani (MV) sebesar Rp 450,-/kg dikalikan potensi hasil panen tanaman maksimum (EY) sebesar 105. 800 $\mathrm{kg} /$ ha sehingga menghasilkan Rp 47. 610. 000,-/ha.

Nilai ALE larva L. stigma instar 1, 2 dan 3 permeter ${ }^{2}$ pada lokasi Tempel Sari misalnya, dapat dihitung dengan mengetahui nilai PL larva instar 1, 2, dan 3 yaitu berturut-turut sebesar 0,0108; 0,0174; dan 0,0221, sedangkan total biaya pengendalian termasuk upah tenaga kerjanya (TC) sebesar Rp 2. 500. 000,-/ha, nilai tanaman (CV) sebesar Rp 47. 610. 000,-/ha dan nilai proporsi penurunan populasi hama karena tindakan pengendalian (PC) sebesar 0,70. Jika nilai TC, CV, PL dan PC dimasukka ke dalam model ALE Bode \& Calvin (1990), maka akan menghasilkan nilai ALE instar 1, 2 dan 3 pada Tempel Sari berturut-turut sebesar 6,97; 4,31; dan 3,39. Sedangkan nilai AE instar 1, 2 dan 3 pada Tempel Sari yang merupakan perhitungan $80 \%$ dari nilai ALE tersebut yaitu berturutturut sebesar 5,58; 3,45; dan 2,71.

Nilai ALE merupakan dasar penentuan nilai AE untuk pengambilan keputusan pengendalian di lapangan yaitu pengendalian secara hayati dengan NEP Steinernema spp. yang dikombinasikan dengan light trap. Nilai AE dihitung dari persentase tetap nilai ALE (fixed economic threshold) sebesar 80\% dari nilai ALE (APRTC, 2002). Semakin tinggi nilai ALE maka semakin tinggi pula nilai AE yang didapat. Nilai ALE dan AE bervariasi berdasarkan tempat dan jenis pengendalian yang digunakan. Perbedaaan nilai tersebut dipengaruhi oleh komponen-komponen 
seperti biaya pengendalian termasuk upah tenaga kerjanya, proporsi kehilangan hasil, efikasi pestisida atau agens hayati, dan faktor lingkungan seperti sifat fisik dan kimia tanah.

Semakin tinggi biaya pengendalian yang dikeluarkan maka semakin tinggi pula nilai ALE, dan AE. Peningkatan nilai ALE dan AE dengan berkurangnya proporsi kehilangan hasil per $\mathrm{m}^{2}$ pada ketiga lokasi. Nilai PC bisa disesuaikan dengan efikasi pestisida maupun agens hayati yang digunakan pada daerah setempat berdasarkan hasil penelitian atau pengalaman petani di lapangan. Nilai tanaman $(\mathrm{CV})$ termasuk harga produk dan potensi hasil panen maksimum diasumsikan sama untuk ketiga lokasi dan jenis pengendalian yang digunakan, baik pada instar 1, 2 dan 3. Semakin tinggi biaya pengendalian dan semakin rendah nilai PC dan PL, maka semakin tinggi nilai ALE dan AE. Semakin rendah nilai CV maka semakin tinggi nilai ALE dan AE jika total biaya pengendalian tetap.

Efikasi dari teknik pengendalian juga merupakan faktor yang perlu dipertimbangkan untuk menentukan posisi nilai AE dari nilai ALE. Apabila teknik pengendalian yang akan digunakan dapat menurunkan populasi hama dalam waktu cepat seperti pengendalian dengan pestisida, maka nilai AE sedikit di bawah nilai ALE. Apabila teknik pengendalian yang digunakan membutuhkan waktu yang lebih lama untuk menurunkan populasi hama seperti dengan menggunakan agens hayati, maka nilai AE jauh di bawah nilai ALE.

Rendahnya nilai ALE dan AE pada Tempel Sari dibandingkan kedua lokasi lainnya dapat dipengaruhi oleh sifat fisik dan kimia tanah yang secara tidak langsung dapat meningkatkan kehilangan hasil. Sifat fisik tanah pada Tempel Sari termasuk kelas tekstur tanah pasir. Sedangkan di Kujon Sari berjenis pasir geluhan dan Grenjeng termasuk jenis geluh pasiran. Jenis tanah berpasir lebih disukai oleh genus Lepidiota daripada tanah liat karena sifatnya yang remah sehingga dapat membantu pergerakan uret tersebut di dalam tanah, apalagi ditunjang dengan kadar air pada kapasitas lapang ( $\mathrm{pF} 2,54)$.

\section{SIMPULAN}

Kesimpulan yang dapat diambil pada penelitian ini sebagai berikut: (1) proporsi kehilangan berat akar yang dimakan setelah diinfestasi larva L. stigma instar 3 lebih tinggi daripada instar 1 dan 2, sehingga akan menyebabkan kehilangan hasil lebih tinggi serta nilai ALE dan AE lebih rendah pada instar 3 daripada kedua instar lainnya pada masing-masing ketiga lokasi; (2) Nilai ALE larva L. stigma pada instar 1, 2, dan 3 persatuan luas meter ${ }^{2}$ untuk pengendalian secara hayati dengan NEP Steinernema spp. yang dikombinasikan dengan light trap, terendah di lokasi Tempel Sari, yaitu larva instar 1 sebesar 6,97 dengan nilai $\mathrm{AE} \mathrm{5,58;}$ instar 2 sebesar 4,31 dengan nilai AE 3,45; dan instar 3 sebesar 3,39 dengan nilai AE sebesar 2,71, sedangkan yang tertinggi di lokasi Grenjeng yaitu larva instar 1 sebesar 15,50 dengan nilai AE 12,40; instar 2 sebesar 9,59 dengan nilai AE 7,67; dan instar 3 sebesar 7,54 dengan nilai AE 6,03; dan (3) Pengambilan keputusan pengendalian dilakukan sedini mungkin yaitu pada saat stadia larva instar 1 yaitu sekitar pertengahan Desember awal Januari dengan memperhatikan " 5 tepat" yaitu tepat dosis, tepat waktu, tepat cara, tepat sasaran, dan tepat jenis.

Saran yang dapat disampaikan sebagai berikut: (1) Nilai ALE dan AE larva L. stigma yang telah diperoleh, dapat dijadikan referensi bagi para petani tebu dan stakeholder yang terkait lainnya sebagai dasar dalam pengelolaan hama, dan (2) Jika waktu pengendalian telah memasuki larva instar 2 dan bahkan instar 3, maka berapa pun besar biaya pengendalian yang dikeluarkan, maka tidak sebanding dengan hasil produksi yang dapat diselamatkan. 


\section{DAFTAR PUSTAKA}

APRTC. 2002. Introduction to Integrated Pest Management. www. sdlearn. net. Diakses 9 juli 2013.

Allsopp, P. G. , Sampson P. and Chandler K. 2000. Pest management. In: Hogarth $\mathrm{M}$ and Allsopp P (eds) Manual of Canegrowing. Bureau of Sugar Experiment Stations, Brisbane, 291337.

Anonim. 1994. Baku Operasional Pengendalian Hama Terpadu Tanaman Tebu. Jakarta.

. 2011. Laporan Akhir Kegiatan Monev Pengendalian OPT Tanaman Semusim. Ditlinbun, Ditjenbun. Kementan, Jakarta.

2012. Kerangka Acuan Kegiatan (Term of Reference) Pengendalian OPT pada Tanaman Tebu. Ditlinbun, Ditjenbun. Kementan, Jakarta.

Barani, A. M. 2013. Swasembada Gula 2014 Sulit Tercapai. Semiloka Gula Nasional 2013. IPB International Convention Center (IICC), Bogor.

Bode, W. M. , and D. D. Calvin. 1990. YieldLoss Relationships and Economic Injury Levels for European Corn Borer
(Lepidoptera: Pyralidae) Populations Infesting Pennsylvania Field Corn. Journal of Economic Entomology 83: 1595-1608.

Higley, L. G. and L. P. Pedigo. 1996. The EIL Concept. Pp. 9-21 in L. G. Higley and L. P. Pedigo (eds. ), Economic thresholds for Integrated Pest Management. Univ. of Nebraska Press, Lincoln, Nebraska, 327 pp.

Kalshoven, L. G. E. 1981. The Pests of Crops in Indonesia. PT. Ichtiar Baru Van Hoeve, Jakarta.

Pedigo, L. P. , S. H. Hutchins, L. G. Higley. 1986. Economic Injury Levels in Theory and Practice. Ann. Rev. Ento. , 31: 341-368.

Pedigo, L. P. 2009. Economic Threshold and Economic injury levels (IPM World Texbook). University of Minnesota. www. ipmworld. umn. edu. Diakses 9 Juli 2013.

Tatchell, G. M. 1989. An Estimate of Potential Economic Losses to Some Crops Due to Aphids in Britain. Crop Protection 8: 25-29.

Untung, K. 2006. Pengantar Pengelolaan Hama Terpadu(Edisi Kedua). Gadjah Mada Univ. Press, Yogyakarta. 